\title{
Contribution of Sports Goods Industry towards Economic Growth of Pakistan
}

\author{
Ijaz Nawaz \\ National College of Business Administration \& Economics \\ DHA Campus Lahore, Pakistan \\ Muhammad Aqib \\ National College of Business Administration \& Economics \\ DHA Campus Lahore, Pakistan \\ Nabeel Shahzad \\ National College of Business Administration \& Economics \\ DHA Campus Lahore, Pakistan \\ Muhammad Yasir \\ National College of Business Administration \& Economics \\ DHA Campus Lahore, Pakistan \\ Dr. Fareeha Zafar \\ Department of Computer Science \\ Government College University, Lahore. Pakistan
}

\begin{abstract}
The research focuses on the prevailing issues and challenges faced by sports goods industry in Pakistan. The share of Pakistan sports goods in total exports of Pakistan is $1.51 \%(2015-16)$ with football as major export product having $43 \%$ share of total sports goods exported in 2012-13 and major export of Pakistan sports goods are to Europe. This study is an attempt to analyze the contribution of sports goods industry in economic growth of Pakistan. This paper depicts importance of sports goods industry for Pakistan. SWOT analysis of Pakistan sports goods industry is presented along statistical values. The results will facilitate sports good industry of Pakistan which exceeds its annual export income of USD 338 million and Sports sectors engaged $\mathbf{2 0 0 , 0 0 0}$ of work force. In addition to this, the paper also presents possible future directions to address aforementioned issues.
\end{abstract}

Keywords: Sports goods, Pakistan, Trade, export

\section{INTRODUCTION}

Sports goods industry of Pakistan plays a vital role in international trade of sports goods. Now, this industry is exporting its products to different countries in the world. These products are manufactured to export according to requirements of international targeted markets. Because of better quality of sports goods Pakistan's sports items gain international fame. Due to its well production process starts from adaptation of raw material to delivering to customers. This process involves better selection of raw material, designing of goods, production process and timely delivering to customer. Pakistan is exporting a large portion of its sports goods from Sialkot to international famous brands like Adidas, Nike, Puma, Lotto, Umbro, Mitre, Micassa, Diador, Wilson and Decathlon. 
We intended to investigate the situation of sports products like sportswear in our country and explore its various aspects. The share of Pakistan sports goods in total exports of Pakistan is $1.51 \%$ (2015-16) with football as major export product having $43 \%$ share of total sports goods exported in 2012-13 and major export of Pakistan sports goods are to Europe. This study is an attempt to analyze the contribution of sports goods industry in economic growth of Pakistan. This paper depicts importance of sports goods industry for Pakistan; it also analyzes the SWOT analysis of Pakistan sports goods industry, while various facts and figures are discussed as well. The Pakistan Sports goods and manufacturing association plays vital role in promotion of this industry. Although Sialkot, situated in the Punjab province of Pakistan, who is expert in producing and exporting sports goods and sport accessories all over the world since 100 years.

Sialkot city was the hub of producing sports goods from history of Pakistan after its independence. When we go back in 1883, first time when Sadar Ganda Sing and Bahadur Sing bring forth the factory to manufacture sports goods for army of British in northern subcontinent.In the factory then they produced cricket bats, polo sticks and hockey sticks. Later, they penetrated into sportswear manufacturing too. Today the sports goods as well as the sportswear sector of Sialkot are at its peak (Elahi, 2013).

\section{STRUCTURE AND TRENDS}

Almost $80 \%$ of the sports goods exported consist of these three sub-sectors; Football, sportswear and Gloves. Manufacturing of sportswear and gloves is done mostly within factories whereas manufacturing of football is considered exceptional and that is a very important process: Normally Football stitching is done within $60 \mathrm{~km}$ from the Sialkot and football stitching is outsourced. Sialkot and the nearby areas of Sialkot city are very important areas and known to the world for the manufacturing of sports goods, the overview and estimates of sports goods and role of Sialkot is as follows (Karim, 2009):

- Firms which are presently working are 300 or more in number that are registered with Pakistan Sports Goods Manufactures and Exports Association (PSGMEA).

- Firms which are registered with Sialkot Chamber of Commerce and Industry are 20k or more in numbers.

- Pakistan's annual exports are more than USD 338 million in 2014-15.

- 1200 and more firms from Sialkot are exporting sports goods.

- About 20k people are associated with this sector. (TRTA, 2010)

As we discuss about sports goods sector it is very promising and have potential sub-sector which is contributes in major sports goods exports. Sialkot city is the first market for buyers to buy sports goods which was imported from Taiwan,South Korea, USA etc. as far as demand became high and imports decreases from other countries, local exporter begins to produce sportswear as well and its followed huge worth in global market (Khan, Haroon, \& Bhatti, 2010).

Table 1: Annual Export of Sports Goods

\begin{tabular}{|c|c|c|c|}
\hline Year & $\begin{array}{c}\text { Total Exports } \\
\text { (0000) }\end{array}$ & Exports of Sports Goods (0000) & \% Share \\
\hline $\mathbf{2 0 1 0 - 1 1}$ & 2481042.2 & 33000.0 & 1.33 \\
\hline $\mathbf{2 0 1 1 - 1 2}$ & 2362425.6 & 33801.9 & 1.43 \\
\hline $\mathbf{2 0 1 2 - 1 3}$ & 2446045.6 & 33422.5 & 1.37 \\
\hline $\mathbf{2 0 1 3 - 1 4}$ & 2510963.9 & 36425.0 & 1.45 \\
\hline $\mathbf{2 0 1 4 - 1 5}$ & 2366729.4 & 33877.6 & 1.43 \\
\hline $\mathbf{2 0 1 5 - 1 6}$ & 1385934.8 & 20984.2 & 1.51 \\
\hline
\end{tabular}

Source: (TDAP, 2016) 
Nawaz, I., Aqib, M., Shahzad, N., Yasir, M., \& Zafar, F. (2017). Contribution of Sports Goods Industry towards Economic Growth of Pakistan. Advances in Social Sciences Research Journal, 4(13) 70-75.

Table 2: Structure of Pakistan's Export by Sports Commodities

\begin{tabular}{|c|l|c|c|c|c|}
\hline \multirow{2}{*}{ SR.NO } & \multirow{2}{*}{ COMMODITIES } & \multicolumn{2}{|c|}{$\begin{array}{r}\text { JULY-FEBRUARY } \\
\mathbf{2 0 1 5}-\mathbf{1 6}(\mathbf{0 0 0})\end{array}$} & \multicolumn{2}{c|}{$\begin{array}{c}\text { JULY-FEBRUARY } \\
\mathbf{2 0 1 4 - 1 5}(\mathbf{0 0 0})\end{array}$} \\
\cline { 3 - 6 } & & Export & $\mathbf{\%}$ Share & Export & \% Share \\
\hline $\mathbf{1}$ & Football (Complete) & 108,396 & 0.78 & 166,926 & 0.71 \\
\hline $\mathbf{2}$ & Gloves Sports & 64,207 & 0.46 & 103576 & 0.44 \\
\hline $\mathbf{3}$ & Other (Sports Goods) & 37,240 & 0.27 & 68274 & 0.29 \\
\hline & Total Sports Goods & $\mathbf{2 0 9 , 8 4 3}$ & $\mathbf{1 . 5 1}$ & $\mathbf{3 3 8 7 7 6}$ & $\mathbf{1 . 4 3}$ \\
\hline
\end{tabular}

(TDAP, 2016)

Table 3: Variation Increase by different Countries (Importance)

\begin{tabular}{|c|c|c|c|}
\hline \multirow{2}{*}{ Countries } & \multicolumn{3}{|c|}{ July- February } \\
\hline & 2015-16 & 2014-15 & VAR. \\
\hline GERMANY & 30,180 & 27,221 & 2,959 \\
\hline UNITED KINGDOM & 22,545 & 19,742 & 2,803 \\
\hline BELGIUM & 9,602 & 9,457 & 145 \\
\hline U.A.E. & 7,084 & 6,280 & 804 \\
\hline DENMARK & 7,048 & 6,088 & 960 \\
\hline CHINA & 5,226 & 2,801 & 2,425 \\
\hline JAPAN & 4,835 & 4,710 & 125 \\
\hline MEXICO & 4,833 & 3,881 & 952 \\
\hline ARGENTINA & 4,712 & 3,489 & 1,223 \\
\hline SOUTH AFRICA & 3,566 & 3,096 & 470 \\
\hline KOREA, REP.OF & 3,102 & 3,065 & 37 \\
\hline INDIA & 1,375 & 1,105 & 270 \\
\hline THAILAND & 937 & 680 & 257 \\
\hline NEW ZEALAND & 779 & 756 & 23 \\
\hline COLOMBIA & 696 & 364 & 332 \\
\hline KENYA & 502 & 484 & 18 \\
\hline EGYPT(U.A.R.) & 452 & 332 & 120 \\
\hline OMAN & 310 & 231 & 79 \\
\hline QATAR & 251 & 171 & 80 \\
\hline IRAN (ISLAMIC R.) & 221 & 33 & 188 \\
\hline INDONESIA & 146 & 125 & 21 \\
\hline VIET NAM & 109 & 24 & 85 \\
\hline JORDAN & 74 & 1 & 73 \\
\hline U.R.OF TANZANIA & 64 & 4 & 60 \\
\hline AFGHANISTAN & 32 & 30 & 2 \\
\hline
\end{tabular}

(TDAP, 2016) 
Table 4: Exports of Pakistan in different countries by Commodities

\begin{tabular}{|l|l|c|c|}
\hline \multicolumn{1}{|c|}{ Commodities } & \multicolumn{1}{|c|}{ Countries } & Qty. (MT) & $\begin{array}{c}\text { Value } \\
\text { (\$0000) }\end{array}$ \\
\hline Sports Leather Gloves & $\begin{array}{l}\text { United State, Germany, United } \\
\text { Kingdom }\end{array}$ & 809 & 3035.8 \\
\hline Ski-Suits, Knitted & United State, Germany, Netherland & 17 & 30.7 \\
\hline $\begin{array}{l}\text { Male Swimwear } \\
\text { (Knitted or Crocheted) }\end{array}$ & United State, Germany, Netherland & 5 & 21.4 \\
\hline Male Swimwear & United State, Italy,United Kingdom & 7 & 17.3 \\
\hline $\begin{array}{l}\text { Female Swimwear Ski Suits } \\
\text { (excl. knitted or crocheted) }\end{array}$ & United State, Australia, Belgium & 2 & 12.4 \\
\hline Ski Suits & Finland, Austria, Belgium & 1 & 1.8 \\
\hline $\begin{array}{l}\text { Ski \& Snow Board Boots. } \\
\text { And leather uppers }\end{array}$ & $\begin{array}{l}\text { France, Canada, United Arab } \\
\text { Emirates }\end{array}$ & 4 & 9.4 \\
\hline Golf Balls & United Kingdom, Spain, Algeria & 35 & 39.4 \\
\hline Badminton Rackets & Ireland, United Kingdom, Germany & 11 & 117.9 \\
\hline Tennis Balls & Germany, Australia, Austria & 3 & 2.9 \\
\hline Inflatable Balls & Germany, United State, Netherlands & 22,016 & 18564.1 \\
\hline Hockey, Cricket and Base-Balls & Netherlands, Germany, United State & 3,745 & 2362.1 \\
\hline $\begin{array}{l}\text { Equipment for General } \\
\text { Physical Exercise \& Other } \\
\text { Sports }\end{array}$ & $\begin{array}{l}\text { Afghanistan, United Arab Emirates, } \\
\text { Australia }\end{array}$ & 20 & 11.1 \\
\hline $\begin{array}{l}\text { Equipment for Sports \& } \\
\text { Outdoor Games }\end{array}$ & $\begin{array}{l}\text { United State, Germany, United } \\
\text { Kingdom }\end{array}$ & 11,479 & 7579.3 \\
\hline
\end{tabular}

(Karim, 2009)

\section{Lack of Technology}

\section{CHALLENGES OF SPORTS GOODS INDUSTRY IN PAKISTAN;}

Less use of technology in sports goods industry is a big concern for the sector, as sports goods industry is mostly working at a small scale, so the adoption of high cost of technology is a bit difficult for this industry. This sector is mainly dependent upon the labor which is less familiar with the use of technology, so it is a problem of this sector in modern days, as technology has its significant importance in today's business and lacks of technology effects the efficiency of the sector.

Our competitors i.e. China, India and Turkey are using much better technology to compete the world.

\section{Power / Energy Shortage}

Energy resources in Pakistan are not sufficient to meet the energy requirements / demand of Pakistani industrial sector, so it is also a big challenge for the sports goods industry in Pakistan. Artificial sources of energy are quite costly and this sector is based on small scale so it can't afford the alternative sources. It may increase the cost of production.

\section{Labor issues}

Sports goods industry has some labor issues like labor unions, labor shortage and labor inefficiency due to their less interest in the work.

We do not have any institution for the training of labor. 


\section{Lack of Govt. interest}

This sector of Exports, sports goods industry is being ignored by the government of Pakistan as there is less interest / concern shown by the government, less government involvement in this sector causes low productivity and less efficiency of the sector.

\section{Less interest of investors in this industry}

Due to the challenges / problems faced by this sector investors are reluctant to invest in sports goods industry.

\section{Security risks}

Security risk has been the major concern for almost every sector /industry of Pakistan since last 15 years or so due to terrorism, as Pakistan having threats of terrorism and instability so it really harms the growth and development of this sector.

Terrorism has affected the image of Pakistan, due to this foreign companies and traders reluctant to come to Pakistan and they lack confidence in dealing with Pakistan.

\section{Heavy tariff on import of machinery}

As this sector requires to import machinery from abroad to improve the methods of production, so it have to pay heavy taxes on import of machinery, which restricts the use of modern machinery in the manufacturing of sports goods.

\section{Role of regulators}

Role of regulatory authorities is very vital in the growth of sports goods industry, Pakistan sports goods manufacturers and exporters association (PSGMEA) is playing their role in the improvement and growth of the industry.

\section{Lack of infrastructure / Facilities}

Infrastructure like roads and transportation facilities helps any industry to grow, as transportation raw material and delivery of manufactured goods is done through the resources available in the country. The transportation facilities and road infrastructure inn Pakistan is not sufficient to meet the requirements of the Pakistan sports goods industry.

\section{Sports condition in Pakistan}

Sports conditions in Pakistan have been adversely affected by the terrorism and it badly affect the stability in the state since one decade. Pakistan is facing huge challenges of terrorism instability, so this sector is suffering also.

\section{Availability of credit facilities}

Sports goods industry is an important contribution to the overall exports of Pakistan, less facilities of credit are available to this sector that may harm the efficiency and growth of sports goods industry in Pakistan. The rate of interest is also on the higher side it is twice as high as in china (i.e. 12\%) in 2013.

\section{No subsidy from government}

Government of Pakistan is not providing any subsidy to sports goods industry in Pakistan due to which this sector is self-reliant in facing the huge challenges of the international competition. (Nawaz, 2016) 


\section{COMMENTS AND CONCLUSION}

At the end of our study we conclude that sports goods industry has played very vital role in the economic development of Pakistan even though this sector has been ignored by the regulators / government of Pakistan, on the basis of our study we recommend / suggest following actions to be taken to enhance the production and growth of this sector;

- Pakistan Sports Goods Manufacturers and Exporters Association (PSGMEA) should play its role to improve the performance of this sector.

- Affordable / subsidized credit facilities should be provided to the sector, so that the sector may use the better and improved technology in production of sports goods.

- Government should provide energy resources as per the requirement of the sector.

- Government should provide subsidy to this sector and reduce the tariff on import of machinery.

- Organized institutes should be established for the training of labor to coup up the labor issues.

- Security conditions of Pakistan need to improve if we want our sports sector to grow. (Nawaz, 2016)

\section{ACKNOWLEDGEMENT}

We acknowledge with deep gratitude the valuable help extended to us by our supervisor Respected Dr. Fareeha Zafar her enouragment and motivation made it possible, we are really thankful to our teachers,colleagues and friends who supported us by giving their useful suggestions.

\section{References}

Arifeen, M. (2010, May 31). Inflating Pakistan's Football Industry. Inflating Pakistan's Football Industry . Punjab, Pakistan: Express Tribune.

Elahi, R. (2013). What is the Capacity of the Pakistani Sportswear. Indus Valley School of Art and Architecture , 40.

Karim, Y. (2009, January 3). Scribd. Retrieved from Scribd.: https://www.scribd.com/doc/11403664/SportsIndustry-in-Pakistan

Khan, U., Haroon, A., \& Bhatti, S. H. (2010). Draft Report on Industrial Sectors. Lahore.

Nawaz, I. (2016, July 21). Pakistan Sports Goods Manufacturers and Exporters Association. (M. Masood, Interviewer) Sialkot, Punjab, Pakistan.

TDAP. (2016). Statistics of Export of Pakistan. Karachi: Trade Developmennt Authority of Pakistan.

TRTA, P. (2010, May 5). Trade Related Technical Assistance. Retrieved from Trade Related Technical Assistance: http://trtapakistan.org/sector-products/industrial-products/sports-goods-appera 